thinking or commercial carelessness permitting some of the situations I have described to get out of hand.

No form of biological development should be allowed to become isolated, otherwise there is a danger that medicine or agriculture may come to be regarded as collections of technical achievements. To permit this loses sight of the interrelationship of human needs and problems, something possibly in the mind of the Apostle Paul when he stressed the dependence of the parts of the body upon each other and the surroundings.

Positive health and preventive medicine in all aspects are as important today as ever. The concept was first propounded by Xenophon over 2,000 years ago in the words: "As there are persons who mend torn garments, so there are physicians to heal the sick; but your duty is far nobler and one befitting a great man-viz. to keep the people in health" (Xenophon, Cyropaedia, i, 6).
I am grateful to Mr. John Reid, Chief Veterinary Officer, and his colleagues in the Ministry of Agriculture, Fisheries and Food for providing much of the up-to-date information incorporated in these lectures.

REFERENCES

Agarwal, S. C. (1962). Bulletin of the World Health Organization, 27,

Anderson, E. S. (1968). British Medical fournal, 3, 333.

Chabbert, Y. A. (1967). Antibiotic News, 3, 1

Couston, T. A., and Campbell, G. (1967). Medical Officer, 117, 114. Devon Farmers Union (1910). Barnstaple Branch Minute Book, 1. Dumont, R. (1969). The Hungry Future, translated by B. Rosier and R. B. Sutcliffe. London, Deutsch.

Galbraith, N. S., Ross, M. S., de Mowbray, R. R., and Payne, D. J. H. (1969). British Medical fournal, 1,612

Kerr, W. R., et al. (1968). Fournal of Medical Microbiology, 1, 181.

Ministry of Technology (1969). Report of the Government Chemist 1968 (chairman: E. Lee). London, H.M.S.O.

Morales, Otero, P. (1929). Puerto Rico fournal of Public Health and Tropical Medicine, 5, 144.

Njoku-Obi, A. N., and Njoku-Obi, J. C. (1965). fournal of Bacteriology, 90, 552 .

Pottenger, F. M. (1946). American fournal of Orthodontics, 32, 467.

\title{
Follow-up Study of Physical Growth of Children Who Had Excessive Weight Gain in First Six Months of Life
}

\author{
E. E. EID,* M.B., D.C.H., D.P.H.
}

Cummary: The aim of this study was to determine whether excessive weight gain in the first six weeks, three months, or six months of life was correlated. with overweight and obesity at the age of 6 to 8 years. One hundred and thirty eight infants with excessive weight gain in the first six months of life, 53 children with slow weight gain, and 33 children with an average weight gain were re-examined at the age of 6,7 , or 8 years.

The mean height and weight of children who had gained weight rapidly in infancy were significantly higher than those of children who had gained weight slowly; those of infants whose weight gain had been average fell in between. The number of obese children in the rapidweight-gain group was significantly higher than that of the combined average and slow-weight-gain groups. The rapidity of weight gain in infancy was a better guide to the risk of overweight in later childhood than the weight of the parents.

\section{Introduction}

The treatment of obesity is difficult and unsatisfactory; it is therefore more important to prevent its development than to wait until the child is severely obese before treating him. It has been suggested that obesity in the early years is likely to be followed by obesity in later childhood and adult life, though Mossberg (1948) claimed that this was true only when there was more than one case of obesity in the family. Asher (1966) compared the subsequent weight of 21 children whose weight was above the 97th percentile in the second half of the first year with that of 24 controls; at 5 years the weight of the former was significantly greater. Asher also found that of 269 children attending an obesity clinic in Birmingham $46 \%$ had been overweight in infancy. Takeya et al. (1967) followed up 101 infants who were overweight in infancy and found that they were overweight three years later.

The present study was planned in order to determine whether excessive weight gain in the first six months presaged overweight in later years.

\footnotetext{
* Research Assistant, Department of Child Health, University of Shef-
} field, Sheffield 10

\section{Methods}

The records of all babies born alive at the Jessop Hospital, Sheffield, in 1961 were reviewed, provided that the babies weighed $2500 \mathrm{~g}$. or more at birth after a gestational period of 38 weeks or more and were followed up at 6 weeks, 3 months, or 6 months of age in the baby clinic. These babies totalled 878,474 of whom were intended for study. They were divided into three groups, on the basis of their weight gain by 6 weeks, 3 months, and 6 months, the tables of Tanner et al. (1966) being used. The groups were as follows:

Group R (rapid weight gain)-306 whose gain was above the 90th percentile.

Group $M$ (average weight gain)-72 whose gain was around the 50th percentile.

Group.S (slow weight gain)-96 whose weight fell below the 10th percentile.

Mothers were asked to bring their children to the Children's Hospital, Sheffield, for measurement. If they were unwilling to come, school health records were used. A total of 178 children were examined personally and data concerning a further 46 were obtained from the school health records. These 224 children fell into the following groups: $R$ 138, M 33, S 53.

The mean birth weight of the children included in the study was virtually the same as that of the original entire group (Table I). The standing height was measured by Har-

TABLE I.-Comparison Between Mean Birth Weights of Original Groups and Followed Groups

\begin{tabular}{|c|c|c|c|c|}
\hline \multirow{2}{*}{\multicolumn{2}{|c|}{ Group }} & \multicolumn{2}{|c|}{ Mean Birth Weight \pm S.D. (kg.) } & \multirow{2}{*}{ Difference } \\
\hline & & Original Groups & Followed Groups & \\
\hline $\begin{array}{l}R \\
M \\
S\end{array}$ & $\begin{array}{l}\cdots \\
\cdots\end{array}$ & $\begin{array}{l}3.364 \pm 0.464 \\
3.405 \pm 0.495 \\
3.554 \pm 0.509\end{array}$ & $\begin{array}{l}3.385 \pm 0.150 \\
3.347 \pm 0.504 \\
3.630 \pm 0.215\end{array}$ & $\begin{array}{l}0.021 \\
0.058 \\
0.076\end{array}$ \\
\hline
\end{tabular}

penden Portable Stadiometer. The child stood bare-footed, with slight traction upwards on the mastoid processes. The head was positioned so that the child was looking directly forward, with the Frankfort plane (external auditory meatus to the lower margin of orbit) and the binauricular plane hori- 
zontal. The weight was measured by an Avery weight-chair machine accurate to the nearest $50 \mathrm{~g}$. Children were weighed wearing their underpants only, for which no correction was made. The triceps and subscapular subcutaneous folds were measured by a Harpenden Skin Caliper. The Tanner and Whitehouse (1962) technique was applied. Most of the mothers were measured personally, while data of the fathers were obtained from their wives.

TABLE II.-Pertinent Data of the Three Groups

\begin{tabular}{ll|c|c|c}
\hline & & $\mathrm{R}$ & $\mathrm{M}$ & $\mathrm{S}$ \\
\hline Total No. &. & 138 & 33 & 53 \\
Males.. &. & 98 & 6 & 18 \\
Females.. & $\cdots$ & $\mathbf{4 0}$ & $\mathbf{2 7}$ & 35 \\
Mean age & $\cdots$ & $\mathbf{5 . 6 0 9 - 8 . 4 7 1}$ & $7.074-897$ & 7.672 \\
Age range &. & & $6.348-8.035$ \\
\hline
\end{tabular}

The pertinent data on each group are given in Table II. The decimal age is used throughout. The $\mathbf{R}$ group contains an excess of males, the other two groups having an excess of females. Thomson (1955) made a similar observation. The height and weight data are expressed as a developmental index (D.I.) (Drash et al., 1968) in order to homogenize the age and sex differences. The developmental index is calculated with the following formula:

$$
\text { D.I. }=\frac{\text { Height or weight age }}{\text { Decimal age }}
$$

The child's actual height or weight was plotted on a Tanner chart, and the age at the median which corresponds to this height or weight is taken as the height or weight age of the child.

The child was considered to be obese if his weight was more than $20 \%$ over the expected weight for his height and sex, Scott's (1961) L.C.C. tables being used, and overweight if his weight was over $10 \%$ more than the expected weight.

The triceps and the subscapular subcutaneous folds measurements are expressed in percentiles, Tanner and Whitehouse percentile charts being used. The age at the follow-up examination was 6 to 8 years.

\section{Results}

At the follow-up examination the mean height and weight of the $\mathbf{R}$ group as assessed by the developmental index was highest, that of the $S$ group was the lowest, while that of the $M$ group was intermediate between the two (Table III). The means of developmental index for height and for weight were significantly greater in the $R$ group than in the $S$ group.

TABLE III.-Mean Developmental Index (D.I.) of Height and of Weight of the Three Groups

\begin{tabular}{|c|c|c|c|}
\hline & $\mathbf{R}$ & $\mathbf{M}$ & s \\
\hline $\begin{array}{l}\text { Mean height D.I. } \pm \text { S.D. } \\
\text { Mean weight D.I. } \pm \text { S.D. }\end{array}$ & $\begin{array}{l}1.087 \pm 0.117 \\
1.103 \pm 0.200\end{array}$ & $\begin{array}{l}1.056 \pm 0.145 \\
1.020+ \pm 0.201\end{array}$ & $\begin{array}{l}1.016^{*} \pm 0.137 \\
0.995^{*} \pm 0.177\end{array}$ \\
\hline
\end{tabular}

$* \mathrm{P}<0.005 . \quad+\mathrm{P}<0.025$.

The incidence of obesity at follow-up is shown in Table IV. The significance of these figures was assessed by contingency tables (Tables V, VI, and VII). When the $M$ and S groups were combined the number of obese children in the $\mathbf{R}$ group was significant. The number of children in group $\mathbf{R}$ who were more than $10 \%$ overweight ( 28 children) was significant when compared with $S$ group alone. The sex incidence in the overweight children was the same.

It is important to note in Table VIII that of those infants who showed excessive weight gain by the sixth week of life $7.4 \%$ were "obese" (as compared with $1.9 \%$ in group S) and
TABLE IV.-Incidence of Obesity and of Overweight

\begin{tabular}{|c|c|c|c|c|}
\hline Group & & $>\underset{\text { Obese }}{20 \% \text { E.W. }}$ & $>10$ to $20 \%$ E.W. & $\begin{array}{l}>10 \% \text { E.W. } \\
\text { Overweight }\end{array}$ \\
\hline $\begin{array}{l}R(138) \quad \ldots \\
M(33) \quad \ldots \\
S(53) \quad \ldots \\
M+S(86)\end{array}$ & $\begin{array}{l}\ldots \\
\cdots \\
\cdots\end{array}$ & $\begin{array}{r}13(9.4 \%) \\
1(3.0 \%) \\
1(1.9 \%) \\
2(2.3 \%)\end{array}$ & $\begin{array}{rr}15 & (10.9 \%) \\
2 & (6.1 \%) \\
2 & (3.5 \%) \\
4 & (4.6 \%)\end{array}$ & $\begin{aligned} 28 & (20.3 \%) \\
3 & (9.1 \%) \\
3 & (5.7 \%) \\
6 & (6.9 \%) \\
& M\end{aligned}$ \\
\hline
\end{tabular}

E.W. = Excess weight over expected weight for height.

TABLE V.-Contingency Table Comparing the Number of Obese Children in $R$ and $S$ Groups

\begin{tabular}{|c|c|c|c|c|c|}
\hline \multicolumn{2}{|c|}{ Group } & \multirow{2}{*}{$\begin{array}{c}\begin{array}{c}\text { Obese } \\
\text { Children }\end{array} \\
13 \\
1\end{array}$} & \multirow{2}{*}{$\begin{array}{c}\begin{array}{c}\text { Non-obese } \\
\text { Children }\end{array} \\
\begin{array}{c}125 \\
52\end{array} \\
\end{array}$} & \multirow{2}{*}{$\begin{array}{r}\text { Total } \\
\begin{array}{r}138 \\
53\end{array}\end{array}$} & \multirow[b]{2}{*}{ Corrected $x_{1}^{2}=2.45(P<0.25)$} \\
\hline $\begin{array}{lll}\mathbf{R} & \cdots \\
\mathbf{S} & \cdots\end{array}$ & $\therefore$ & & & & \\
\hline Total & .. & 14 & 177 & 191 & \\
\hline
\end{tabular}

TABLE VI.-Contingency Table Comparing the Number of Obese Children in $R$ and the Combined $S$ and $M$ Groups

\begin{tabular}{|c|c|c|c|c|c|}
\hline \multicolumn{2}{|c|}{ Group } & \multirow{2}{*}{$\begin{array}{c}\begin{array}{c}\text { Obese } \\
\text { Children }\end{array} \\
\begin{array}{r}13 \\
2\end{array}\end{array}$} & \multirow{2}{*}{$\begin{array}{c}\begin{array}{c}\text { Non-obese } \\
\text { Children }\end{array} \\
\begin{array}{r}125 \\
84\end{array}\end{array}$} & \multirow{2}{*}{$\begin{array}{r}\text { Total } \\
\begin{array}{r}138 \\
86\end{array}\end{array}$} & \multirow[b]{2}{*}{$x_{10}^{2}=5.21 \quad(P<0.025)$} \\
\hline$\stackrel{\mathbf{R}}{\mathbf{S}}+\ddot{\mathbf{M}}$ & 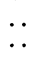 & & & & \\
\hline Total & $\ldots$ & 15 & 209 & 224 & \\
\hline
\end{tabular}

TABLE VII.-Contingency Table Comparing the Number of Overweight Children in $R$ and $S$ Groups

\begin{tabular}{|c|c|c|c|c|c|}
\hline \multicolumn{2}{|c|}{ Group } & \multirow{2}{*}{$\begin{array}{c}\begin{array}{c}\text { Overweight } \\
\text { Children }\end{array} \\
28 \\
3\end{array}$} & \multirow{2}{*}{$\begin{array}{r}\text { Rest } \\
\begin{array}{r}110 \\
50\end{array}\end{array}$} & \multirow{2}{*}{$\begin{array}{r}\text { Total } \\
\begin{array}{r}138 \\
53\end{array}\end{array}$} & \multirow[b]{2}{*}{$x_{1}^{2}=5.79(P<0.025)$} \\
\hline $\begin{array}{ll}\mathbf{R} & . \\
\mathbf{S} & . \\
\end{array}$ & 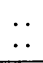 & & & & \\
\hline Total & $\ldots$ & 31 & 160 & 191 & \\
\hline
\end{tabular}

TABLE VIII.-Effect of Age of Detection of Excess Gain in Weight in First Year in R Group on the Incidence of Obesity and of Overweight

\begin{tabular}{|c|c|c|c|}
\hline Age of Detection & No. & $\begin{array}{l}\text { Obese } \\
\text { Children } \\
(>20 \%)\end{array}$ & $\begin{array}{l}\text { Overweight } \\
\text { Children } \\
(>10 \%)\end{array}$ \\
\hline $\begin{array}{l}\text { (1) At } 6 \text { weeks only } \\
\text { (2) At } 6 \text { weeks and } 3 \text { rd or } 6 \text { th month } \ldots \\
\text { (3) All children detected at } 6 \text { weeks }(1+2) \\
\text { (4) At } 6 \text { months only } \ldots \quad \ldots\end{array}$ & $\begin{array}{r}73 \\
35 \\
108 \\
30\end{array}$ & $\begin{array}{l}3(4.1 \%) \\
5(14 \cdot 2 \%) \\
8(7 \cdot 4 \%) \\
5(16 \cdot 7 \%)\end{array}$ & $\begin{array}{r}13(17 \cdot 8 \%) \\
7(20.0 \%) \\
20(18.5 \%) \\
8(26.7 \%)\end{array}$ \\
\hline
\end{tabular}

$18.5 \%$ were overweight. Of those who showed an excessive weight gain at the sixth month of age $16.7 \%$ were obese and $26.7 \%$ were overweight.

Interestingly, the mean birth weight of group $S$ was significantly higher than that of group $R$ (difference $0.245 \mathrm{~kg}$., $t=8.816, P<0.005)$. This may be related to the more rapid weight gain in infants of low birth weight. Thomson (1955) made a similar observation. Yet the babies with low birth weight of the $\mathbf{R}$ group showed a slightly lower incidence of obesity later (Table IX). There was no significant difference between breast-fed and artificially fed babies with regard to

TABLE IX.-Effect of Birth Weight Subgroups on Incidence of Obesity and of Overweight in $R$ Group

\begin{tabular}{|c|c|c|c|c|c|c|c|}
\hline \multicolumn{5}{|c|}{ Birth Weight Subgroups } & \multirow{2}{*}{$\begin{array}{l}\text { No. } \\
15 \\
97 \\
26\end{array}$} & $\begin{array}{c}\begin{array}{c}\text { Obese } \\
\text { Children } \\
(>20 \%)\end{array} \\
\end{array}$ & \multirow{2}{*}{$\begin{array}{c}\begin{array}{c}\text { Overweight } \\
\text { Children } \\
(>10 \%)\end{array} \\
\begin{array}{r}1(6 \cdot 7 \%) \\
20(20 \cdot 6 \%) \\
5(19 \cdot 2 \%)\end{array}\end{array}$} \\
\hline $\begin{array}{l}\text { Below } 2.75 \mathrm{~kg} . \\
2.75-3.75 \mathrm{~kg} \text {. } \\
\text { Over } 3.75 \mathrm{~kg} \text {. }\end{array}$ & $\begin{array}{l}\ldots \\
\cdots\end{array}$ & $\therefore$ & $\begin{array}{l}\cdots \\
\cdots\end{array}$ & $\begin{array}{l}\cdots \\
\cdots\end{array}$ & & $\begin{array}{l}1 \\
1 \\
9 \\
3(6.7 \%) \\
3(11.5 \%)\end{array}$ & \\
\hline
\end{tabular}

subsequent obesity (Table $\mathrm{X}$ ). The weight gain in infancy proved to be a better predictor of overweight later than did the parents' weight. Of 20 children in group $\mathbf{R}$ who had one overweight parent (over 14 stones; $88.9 \mathrm{~kg}$.), only two were 
TABLE X.-Incidence of Breast and Artificial Feeding in $R$ Group and its Effect on the Incidence of Obesity and of Overweight

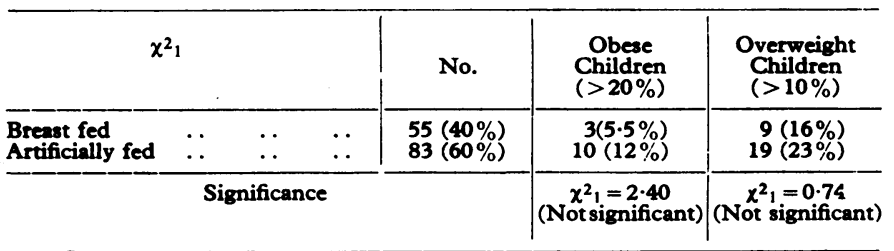

obese, the same incidence as that of the group as a whole. Only personally obtained data were used for measurement of the triceps and subscapular folds (Tables XI and XII). The thickness of the subscapular folds at follow-up was significantly greater in the $\mathbf{R}$ group than in the $\mathbf{S}$ group.

TaBLE XI.-Triceps Subcutaneous Fold Percentile Distribution

\begin{tabular}{|c|c|c|c|c|c|c|c|c|c|}
\hline Group & No. & $\begin{array}{c}\text { Percentile } \\
\text { Group }\end{array}$ & $3-$ & $10-$ & 25 & $50-$ & $75-$ & $90-$ & 97- \\
\hline $\mathbf{R}$ & 106 & $\left\{\begin{array}{l}\text { No. } \\
\%\end{array}\right.$ & $\begin{array}{c}3 \\
2 \cdot 8\end{array}$ & $\begin{array}{c}5 \\
4 \cdot 7\end{array}$ & $\begin{array}{l}19 \\
17.9\end{array}$ & $\begin{array}{c}33 \\
31 \cdot 1\end{array}$ & $\begin{array}{c}22 \\
20 \cdot 8\end{array}$ & $\begin{array}{c}15 \\
14 \cdot 2\end{array}$ & 89 \\
\hline $\mathbf{M}$ & 30 & $\begin{array}{l}\text { No. } \\
\%\end{array}$ & $\begin{array}{c}1 \\
3 \cdot 3\end{array}$ & $6 \cdot 2$ & $\begin{array}{c}3 \\
10\end{array}$ & $\begin{array}{l}13 \\
43 \cdot 3\end{array}$ & $\begin{array}{c}5 \\
16 \cdot 7\end{array}$ & $\begin{array}{c}4 \\
13 \cdot 3\end{array}$ & $\underset{6 \cdot 7}{2}$ \\
\hline$S$ & 42 & $\begin{array}{l}\text { No. } \\
\%\end{array}$ & $\begin{array}{c}1 \\
2 \cdot 4\end{array}$ & $\begin{array}{c}2 \\
4 \cdot 8\end{array}$ & $\begin{array}{c}6 \\
14 \cdot 3\end{array}$ & $\begin{array}{c}12 \\
28 \cdot 6\end{array}$ & $21 \cdot 4$ & $\begin{array}{c}9 \\
21 \cdot 4\end{array}$ & $\begin{array}{c}3 \\
7 \cdot 1\end{array}$ \\
\hline
\end{tabular}

TABLE XII.-Subscapular Subcutaneous Fold Percentile Distribution

\begin{tabular}{|c|c|c|c|c|c|c|c|c|c|c|}
\hline Group & No. & $\begin{array}{l}\text { Percentile } \\
\text { Group }\end{array}$ & $<3$ & $3-$ & $10-$ & 25 & $50-$ & $75-$ & $90-$ & $97-$ \\
\hline $\mathbf{R}^{*}$ & 106 & 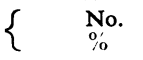 & $\begin{array}{c}6 \\
5 \cdot 7\end{array}$ & $\begin{array}{l}10 \\
9 \cdot 4\end{array}$ & $\begin{array}{l}20 \\
18.9\end{array}$ & $\begin{array}{l}28 \\
28\end{array}$ & $\begin{array}{c}20 \\
18.9\end{array}$ & $\begin{array}{c}7 \\
6 \cdot 6\end{array}$ & $\begin{array}{r}11 \\
10 \cdot 4\end{array}$ & $\begin{array}{r}4 \\
3.8\end{array}$ \\
\hline$M$ & 30 & $\begin{array}{l}\text { No. } \\
\%\end{array}$ & $\begin{array}{c}1 \\
3 \cdot 3\end{array}$ & $\begin{array}{c}5 \\
16 \cdot 7\end{array}$ & $\begin{array}{c}7 \\
23 \cdot 3\end{array}$ & $\begin{array}{c}7 \\
23 \cdot 3\end{array}$ & $\begin{array}{c}3 \\
10\end{array}$ & \begin{tabular}{c|}
4 \\
$13 \cdot 5$
\end{tabular} & $\begin{array}{c}2 \\
6 \cdot 7\end{array}$ & $\begin{array}{c}1 \\
3 \cdot 3\end{array}$ \\
\hline $\mathbf{S}^{*}$ & 42 & No. & $\begin{array}{c}3 \\
7 \cdot 1\end{array}$ & $\begin{array}{c}5 \\
11.9\end{array}$ & $\begin{array}{c}1 \\
2 \cdot 4\end{array}$ & $\begin{array}{l}11 \\
26 \cdot 2\end{array}$ & $\begin{array}{c}14 \\
33 \cdot 3\end{array}$ & 9.5 & $\begin{array}{c}2 \\
4 \cdot 8\end{array}$ & $\begin{array}{c}2 \\
4 \cdot 8\end{array}$ \\
\hline
\end{tabular}

${ }^{*} \chi^{2}{ }_{1}=14 \cdot 43, P<0 \cdot 05$. (Yates's correction)

\section{Discussion}

It is disturbing to find that unusually rapid weight gain in the early weeks - as early as 6 weeks of age-is related to overweight and obesity in later childhood. Those who have continually claimed that overfeeding is a myth may have to revise their views. Further investigation is required to deter- mine whether those who had an unusually rapid weight gain took more milk than others, or whether they had an earlier introduction to cereals than those whose weight gain was slower.

Infants with a lower birth weight tended to gain weight more rapidly than those with a higher birth weight, and therefore were at a greater risk of subsequent obesity. Wolff (1955) suggested that the normal birth weight of obese children implied that childhood obesity is generally acquired, though some children may have an abnormal appetiteregulatory mechanism as an inherited condition.

Prevention is better than attempted cure. Illingworth (1968) suggested that infants and children should be weighed regularly in order that preventive action can be taken immediately a significant departure from the normal weight pattern manifests itself. Periodic visits to the baby clinic or the family doctor should reveal early excessive weight gain. Mothers should be instructed not to start the sweet-eating habit, and not to encourage constant eating-for example, potato crisps-between meals. They should limit the amount of milk taken by the child to a pint $(570 \mathrm{ml}$.) per day. Unduly early introduction of cereals-for example, in the first month or two-may well be unwise.

I am grateful to Professor R. S. Illingworth for his continuous supervision and encouragement, to Professor $J$. Knowelden for statistical advice, and to Dr. F. Harris for helpful criticism. I am indebted to Dr. J. C. MacInnes, Dr. F. C. Armstrong, Dr. J. T. Clow, and Dr. D. J. Cluster for the school health data, and to Mr. N. T. Parker and Mr. B. England, Clerks of the Executive Councils of Sheffield and the West Riding, for help with addresses.

I am grateful for the financial support given by the British Council and the University Research Fund.

\section{REFERENCES}

Asher, P. (1966). Archives of Disease in Childhood, 41, 672.

Drash, A., Heese. D., and Brasel, J. A. (1968). In Human Growth, edited by D. B. Cheek. p. 60. Philadelphia, Lea and Febiger.

Illingworth, R. S. (1968). The Normal Child 4th ed. London, Churchill. Mossberg, H.-O. (1948). Acta Paediatrica Scandinavica, 35, Suppl. No. 2 , Mossberg,

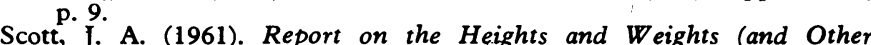
Measurements) of School Pupils in the County of London in 1959. Measurements) of School Pupils

Takeya, H., Okada, T., and Kaneda, S. (1967). Acta Paediatrica faponica (overseas ed.), 9, 28.

Tanner, J. M., and Whitehouse, R. H. (1962). British Medical fournal, 1,446

Tanner, J. M., Whitehouse, R. H., and Takaishi, M. (1966). Archives of Disease in Childhood, 41, 613.

Thomson, J. (1955). Archives of Disease in Childhood, 30, 322.

Wolff, O. H. (1955). Quarterly fournal of Medicine, 24, 109.

\section{Pregnancy and Crohn's Disease}

\section{J. F. FIELDING, ${ }^{*}$ M.B., B.SC., M.R.C.P. ; W. T. COOKE, $†$ M.A., M.D., F.R.C.P.}

\begin{abstract}
ummary: Of 77 married women with Crohn's disease, 25 were sterile. In the remaining 52 (98 pregnancies) the risks of prematurity, stillbirth, abortion, or congenital abnormality were not increased. There was no evidence that pregnancy exerted adverse effects on the course of the disease or increased the mortality rate. Sterility was the main problem encountered.
\end{abstract}

\section{Introduction}

Only one major report, that by Crohn, Yarnis, and Korelitz (1956), has been published dealing with the interactions between pregnancy and Crohn's disease. The disorder itself has become more readily recognized and possibly even increased in incidence. As some patients are still advised to avoid pregnancy or to have their pregnancy terminated, it seemed opportune to reconsider the problem and review our experience.

\section{Patients Studied}

Of 300 patients with regional enteritis followed up between 1944 and 1969, 157 were women. Of these, 19 had died and 